第 3 表 ケイ酸塩中のバリウムの定量

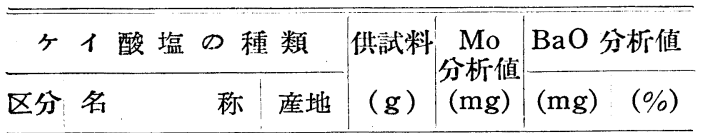

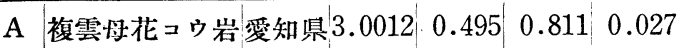

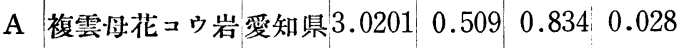

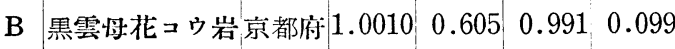

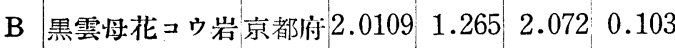

\begin{tabular}{lll|l|l|l|l} 
C & 黑雲母花コウ岩京都府 1.5004 & 0.781 & 1.279 & 0.085
\end{tabular}

\begin{tabular}{llll|l|l|l|l}
$\mathrm{D}$ & 流 & 紋 & 岩杤木県 & 1.5030 & 1.128 & 1.848 & 0.123
\end{tabular}
ケイ酸滥についての実験結果は第 3 表のようで良好な結 果か得られた。第 3 禀中の同じ区分のものはそれぞれ同 一試料について分析したものである。

終りに終始御想篤な御指導を賜わった九州大学理学部 の吉村 沟教授ならびに原子力研究所の石森富太郎先生 に厚く御礼申し上げる。またケイ酸塩の試料を提供して 下さった当学部鉱山学教室の內田信義教授に感謝致しま す。

（昭和 31 年 4 月，日本化学会第 9 年会荫演）

（東京工業大学資源化学研究所，東京都目黑区）（昭和 31 年 5 月 25 日受理）

\title{
赤外吸収による石炭の研究（第 1 報）
}

\author{
児島邦夫・坂下潔・吉野常夫
}

石炭の構造については現在まだほとんぞわかっていな い。てれは石炭が非常に複雑な物質であることと其に， その構造をそのままの状態で知る方法が確立されていな かったことにも理由があうう。構造をそのままの状態で 知るのには物理的研究方法がよいが，その中で赤外吸仪 スペクトルの利用が有望と思われる。

1945 年以降, 石炭の赤外スペクトルについてはいくつ かの報告があるが，薄片を用いたり1， ヌジォールや ヘキサクロルブタジエン等の分散媒を用いるため22334), 試料の作成あるいは測定結果について多くの難点があっ た。

試料調製の具化カリウム鏔剤注は媒筫の吸収に妨害さ れず定量が可能で，しかもきわめて微量でも测定が行え る等の諸点で，一般固体試料の測定に大きな進歩をもた らした。固体の試料をそのまま測定できるての方法は， 石宸の構造研究にとって最適のものといえよう。すでに ての方法による石宸の研究も一，二あらわれ始めた5)6)。

鈽剤法についてはその後多くの研究改良が行われ，有 用性が多数の人に注目され，錠剤成型用の市販品（米国

1) C. G. Cannon, G. B. B. M. Sutherland, Trans. Faraday Soc. 41, 279 (1945).

2) B. R. Gordon, W. N. Adams, G. J. Jenkins, Nature 170, 317 (1952)

3) J. K. Brown, J. Chem. Soc. 1955, 744, 752

4) C. G. Cannon, Nature 171, 308 (1953).

5) H. A. van Vucht, B. J. Rietveld, D. W. van Krevelen, Fuel 34, 50 (1955)

6) V. G. Bergman, G. H. Huck, J. Karweil, H. Luther, Brennstoff-Chem. 35, 175 (1954).
製）がある。しかし市販品ははなはげ高価なので，われ われは従来のものを参考隹，いくつかの単純化と工夫を 加え，後述のような製作費の安い，使用しやすいものを 設計製作した。

さいわい，われわれは本邦座石炭の微粉試料を本田博 士と村田氏より頂戴するととができたので，この測定を

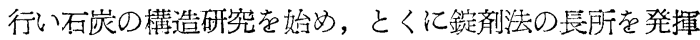
できる $\mathrm{C}-\mathrm{H}$ 伸縮領域についてフッ化リチウムプリズム による研究を試みた。

\section{臭化カリゥム錠剤型と成型法}

現在使用している装置 (Perkin-Elmer 112 型赤外分 光光度計）の保持台にそのまま使え，また普通の臭化力 リウム窓もこの方法で製作するてとを考えにいれ，錠剤 の大きさはやや大きい径 $25 \mathrm{~mm}$ とした。成型用器具は 第1四に示したように高さ約 $14 \mathrm{~cm}$, 直径約 $13 \mathrm{~cm} の$ 鋼製円筒（F）认鋼製の底（D)，蓋をつけ，その中亿 高硬度の工具鋼にクロムメッキを施した“き权”（A) “うす”（BとC）を插入した。気密は（E）および (G)の輪ゴムと（H）のゴムのシールで保たれ，（I） のねじをしめて蓋を内筒汇押しつけることによって確実 にした。

鉈剤を作るには，まず市販特級の臭化カリウムを霞気

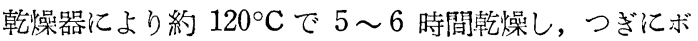
ールミルで $5 \sim 6$ 時間粉砕する。乙れを $3 \sim 4$ 回繰返し て，300メッシュの微粉とする。後述の不炭の測定の例 


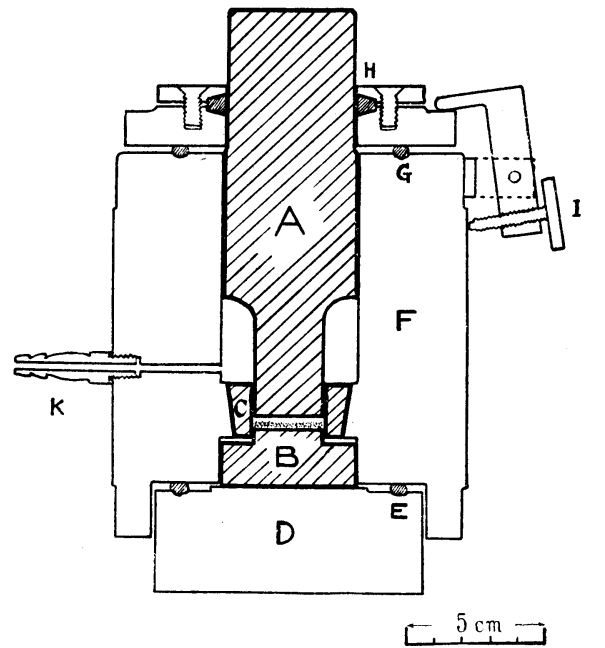

第 1 図臭化カリウム錠㓣成型用器具

で脑 $7 \mathrm{mg}$ の微粉試料を $0.7 \mathrm{~g}$ の臭化カリウム微粉と共 にメノウの乳鉢で混合する。てれを型の $(\mathrm{A})$ と（B) の間沉れ， $(\mathrm{K})$ より 3〜 $15 \mathrm{mmHg}$ で 5 分はど排気し た後,排気しながら油圧プレスで約 5 分間加圧成型する。 プレスの圧力は全圧約 $30 \mathrm{t}$ である。加圧終了後型の底 （D）をとり去り，型を倒置して軽く加圧すると“うす” の底 (B) が外れて, 錠剤が取り出せる。上述の条件で

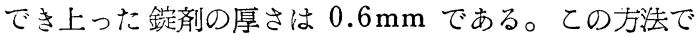
作られた莫化カリウム錠剤は完全に透明であり，その透 明度法デシケーター中では長時間後にもほとんど変化し ない。との赤外スペクトルをとると，不純物としてわず かにボールミルで粉碎中に混入したと思われるケイ酸の 吸収が見られる。しかし，てれはでく弱い幅広い吸収な ので通常の測定には美支えない。

\section{石炭の赤外吸収}

試料はいずれも微粉にした後，真空デシケーター中で 五酸化リンにより長時間乾燥したものである。測定は Perkin-Elmer 112 型分光光度計に塩化ナトリウムおよ びフッ化リチウムプリズムをつけ 670 ～ $3850 \mathrm{~cm}^{-1}$ の領 域で行った。

第 1 表江三池炭（比重 $<1.25 ）$ の測定結果を示した。 他の 3 試料も相対強度に幾分の相違はあるが，乙れとほ ぼ同様の位置に吸収を示した。また吸収の位置は同程度 の炭素含量の外国炭について報告された結果了到ともほぼ 一致した。測定された吸収の形はいずれも幅広く，とく に $1000 \mathrm{~cm}^{-1}$ から $1300 \mathrm{~cm}^{-1}$ の領域ではほとんど連 続吸収である。
第 1 表 石炭の赤外吸収スペクトル $\left(\mathrm{cm}^{-1}\right)$ （三池炭，比重 $<1.25 ）$

\begin{tabular}{|c|c|c|c|}
\hline 751 & $1010 \sim 1110 \mathrm{~m}$ & $1608 \mathrm{~s}$ & $3033 \mathrm{w}$ \\
\hline 816 & $1150 \sim 1300 \mathrm{~s}$ & 2848 & $3280 \mathrm{~m}$ \\
\hline 873 & $1372 \mathrm{~s}$ & 2918 vs & $3390 \mathrm{~m}$ \\
\hline 997 & 1450 vs & $2948 *$ & \\
\hline
\end{tabular}

* 吸収の肩.

吸収帯の帰属： 751,816 および $873 \mathrm{~cm}^{-1}$ の吸収は 主として石炭の中に含まれる多くの単環，あるいは縮合 環化合物の $\mathrm{C}-\mathrm{H}$ 面外振動澹属される。

690 〜 $720 \mathrm{~cm}^{-1}$ 付近治強い吸収がないてとからベンゼ ンのモノー,メター, 1,2,3-，1,3,5-置換体の存在はきわ めてわずかであるといえる。 $751 \mathrm{~cm}^{-1}$ は主としてベン ゼンのオルト置換体，縮合環化合物では㯰換基を持たぬ 端の環によるものである。 $816 \mathrm{~cm}^{-1}$ は隣接した 2 個の 水素原子を有する芳香族， $873 \mathrm{~cm}^{-1}$ は孤立した水素原 子を有する芳香族の特性振動であうう。

1000 1300 $\mathrm{cm}^{-1}$ の領域の吸収の強度がかなり強いの は, C-O-H, C-O-C 等の 構造が存在するためと思わ れる。1372 $\mathrm{cm}^{-1}$ は主として $-\mathrm{CH}_{3}$ の变危振動, 1450

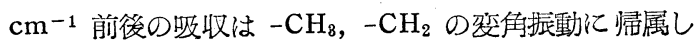
うる。. $1608 \mathrm{~cm}^{-1}$ は芳香族の環の振動と一応考えられる が，その強度が著しく大きいわけは，フェニルエーテル 型の環の振動，あるいはベンゾキノン，アンスラキノン 構造, キレート構造等によって振動数が低下した $\mathrm{C}=\mathrm{O}$ 振動等による可能性が考えられる。

$2848,2918,2948 \mathrm{~cm}^{-1}$ の吸収は脂肪族の $-\mathrm{CH}_{3}$, $-\mathrm{CH}_{2}$ 伸縮振動代, $3033 \mathrm{~cm}^{-1}$ は主として芳香族の $-\mathrm{CH}$ 伸縮振動深属しうる。後者にはオレフィンの $=\mathrm{C}-\mathrm{H}$ 伸 縮振動による部分も含まれていよう。 $3280,3390 \mathrm{~cm}^{-1}$ を中心とする幅広い吸収は水素結合を形成した主として $\mathrm{O}-\mathrm{H}$ 伸縮振動によるものと思われる。

$\mathbf{C}_{\text {arom }}-\mathbf{H}$ と $\mathbf{C}_{\text {aliph }}-\mathbf{H}$ の吸収強度：4 種の試料中の 芳香族の $\mathrm{C}_{\text {arom }}-\mathrm{H}$ 絓合による吸収と飽和脂肪族の $\mathrm{C}_{\text {aliph }}-\mathrm{H}$ 綪合のそれとの相対強度を比較するために, フッ化リチウムプリズムを用い $0.160 \mathrm{~mm}$ のスリット 幅で定量を行った。ての領域のスペクトルの一例（矢盾 炭）を第 2 㓙仁示した。C aliph-H 絓合を代表するもの として $2918 \mathrm{~cm}^{-1}$ の吸收を選び，その光学密度 $d_{\mathrm{aliph}}$ と，主として C $\mathrm{arom} \mathrm{H}$ 綪合による $3033 \mathrm{~cm}^{-1}$ の吸収 の光学密度 $d$ arom を比輘した結果を第 2 表虽げた。 $d$ は $\log I_{0} / I$ である。 $I_{0}$ は “base-line”法を用い， $3033 \mathrm{~cm}^{-1}$ の吸収注 $2918 \mathrm{~cm}^{-1}$ と $3280 \mathrm{~cm}^{-1}$ の吸 


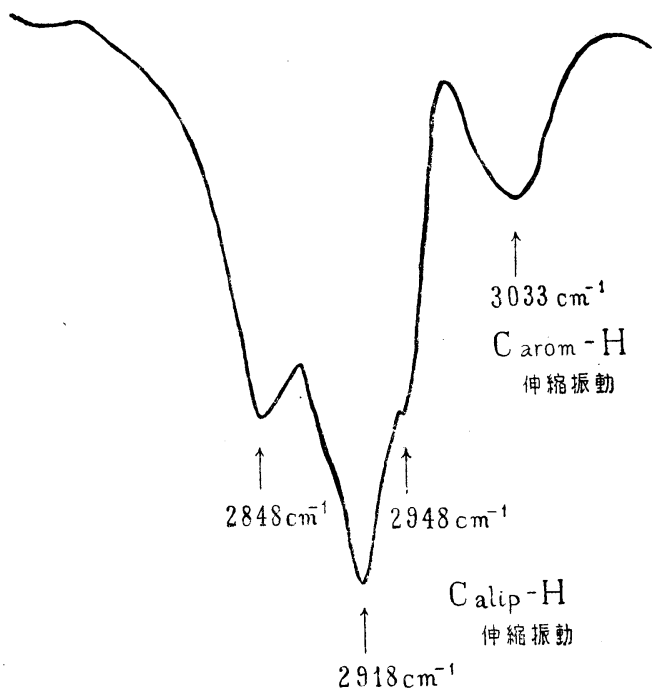

第 2 図 矢岳炭の赤外スペクトル

(C-H 結合仲縮振動の領域)

収のすその重なりを考慮した補正を加えた。

第 2 表 各種石炭に扣ける $\mathrm{C}_{\mathrm{arom}}-\mathrm{H}$ 結合と

$\mathrm{C}_{\text {aliph }}-\mathrm{H}$ 結合による吸収強度の比較

\begin{tabular}{|c|c|c|c|c|c|c|c|}
\hline \multirow{2}{*}{\multicolumn{2}{|c|}{ 石炭の種類 }} & \multicolumn{2}{|c|}{$d=\log I_{0} / I$} & \multirow{2}{*}{$\begin{array}{c}d_{\text {arom }} / \\
d_{\text {aliph }}\end{array}$} & \multicolumn{3}{|c|}{$\begin{array}{l}\text { 重 量 百分 率* } \\
\text { (無水無灰炭とて) }\end{array}$} \\
\hline & & & $\begin{array}{l}3033 \\
\mathrm{~cm}^{-1}\end{array}$ & & 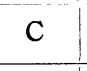 & $\mathrm{H}$ & $\mathrm{O}$ \\
\hline F & 炭 & & & & & 5.09 & \\
\hline & 炭 & & & & & 6.1 & .2 \\
\hline & $.25 \sim 1.30$ & & & & 84.03 & 5.78 & $7: 4$ \\
\hline & 比重 $<1$ & & $0.04_{9}$ & 0.07 & 83.74 & 6.05 & 7.93 \\
\hline
\end{tabular}

* 石炭の元素分析値は, 村田氏（三池合成）に上り 提供されたものである.

第 2 区および第 2 表の $d_{\text {arom }} / d_{\text {aliph }}$ の值から，乙れ らの不宸中の 飽和脂肪族の $\mathrm{C}_{\text {aliph }}-\mathrm{H}$ 結合による吸収 が，芳香族の $\mathrm{C}_{\text {arom }}-\mathrm{H}$ 絓合のそれにくらべて著しく強
いととがわかる。しかし，各結合 1 個あたりの吸収強度 は前者が大であるから，見かけほど Caliph-H 結合が多 いとはいえないが，石炭中で飽和脂肪族炭化水素のしめ る部分が案外大きいといえる。

つぎに炭素含量のほぼ等しい夕張孷と三池炭で浊，吸 収強度の比, したがって C arom-H 結合と Caliph-H 綪 合の数の此はほとんど变らないが，てれより炭素含量の 高い矢岳孷では約 4 倍に増加している。ての変化は, $\mathrm{C}_{\text {aliph }} \mathrm{H}$ 絓合が約半分に減少し， C $\mathrm{Carom}-\mathrm{H}$ 結合が約倍 亿堌加したてとによる。すなわち，同じ石炭でも矢岳宸 と, 夕張炭, 三池崖との閒には構造上かなり莠しい相違 があることが注目される。

もしての違いが一つの石炭過程の段際によるものだと すれば, 夕張炭, 三池炭から矢岳炭へ, すなわち炭素含 量約 84\% 加ら $89.5 \%$ への炭化過程污いて, 飽和脂 肪族炭化水素が芳香族炭化水素へ相当多量变化すること を示している。

なお三池炭については同一炭を比重の異なる 2 部分に わけて測定したが， $d$ arom/ $d$ aliph にははとんど相違が 認められなかった。

吸収強度から $\mathrm{C}_{\text {aliph }}-\mathrm{H}$ 結合と $\mathrm{C}_{\text {arom }}-\mathrm{H}$ 結合の数を

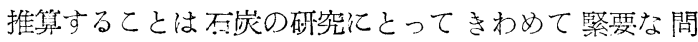
題である。しかし，そのためには上にも述べたように， 綪合 1 個あたりの昅光係数の比 Earom/Ealiph 党知ら放 ばならない。この值は，今後の砩究で石岸の構成票素て 近いと思われる構造既知の化合物をいくつか探し出し， これらのものの Earom/Ealiph の值汃ら推定したい。

以上において，赤外吸収加代表的な本邦㢈石孷にか なり多くの飽和脂肪族㟶化水素部分が存在すること，お

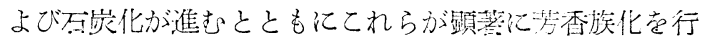
うことが明らかとなった。

試料を提供して下さった资源技術硬究所の本日英昌博 士，三池合成工業株式会社の村四富二郎氏汇深謝する。

(昭和 30 年 10 月, 赤外ラマンスペクトル討諭会(一 部）潇演）

(金沢大学理学部化学教室, 金沢市)（昭和 31 年 5 月 25 日受理）

\section{酢酸第ニコバルトの製造とその性質について}

森元七・久野栄進・柴田村治

3 価のコバルト塩はいわゆる典型的錯塩の形ではたく さん合成され，いろいろと䂺究されているが，不安定錯
塩の形のものについては，あまり研究されていない。こ てでとりあげた酶酸第二コバルトは，後者に属するもの 